\title{
Autospecific $\gamma \delta$ thymocytes that escape negative selection find sanctuary in the intestine
}

\author{
Tesu Lin, ${ }^{1}$ Hiroki Yoshida, ${ }^{2}$ Goro Matsuzaki, ${ }^{2}$ Sarah R. Guehler, ${ }^{3}$ Kikuo Nomoto, ${ }^{2}$ \\ Terrence A. Barrett, ${ }^{3}$ and Douglas R. Green ${ }^{1}$ \\ ${ }^{1}$ Division of Cellular Immunology, La Jolla Institute for Allergy and Immunology, San Diego, California 92121, USA \\ ${ }^{2}$ Department of Immunology, Medical Institute of Bioregulation, Kyushu University, Fukuoka 812, Japan \\ ${ }^{3}$ Gastroenterology and Hepatology Section, Department of Medicine, Northwestern University, Chicago, Illinois 60611, USA
}

Address correspondence to: Tesu Lin, 10-541 Searle, Gastroenterology Section, Department of Medicine, Northwestern University Medical School, 330 E. Chicago, Chicago, Illinois 60611, USA.

Fax: (312) 908-6192; E-mail: ndorachan@yahoo.com.

Received for publication May 26, 1999, and accepted in revised form September 27, 1999.

$\alpha \beta$ or $\gamma \delta$ thymocytes whose T-cell receptors (TCRs) recognize endogenously expressed antigens (Ag) are autospecific and, thus, potentially self-reactive. In the thymus, such $T$ cells are eliminated during T-cell development through a process known as negative selection. As a model of negative selection of $\gamma \delta$ T cells, we have used G8 $\gamma \delta$-T cell transgenic mice, which express a $\gamma \delta$ TCR that recognizes the nonpolymorphic MHC class I TL ${ }^{\mathrm{b}}$ molecule. Here, we demonstrate that negative selection of autospecific $\gamma \delta \mathrm{T}$ cells is almost complete in the adult thymus but is markedly attenuated in the neonatal thymus. A consequence of this attenuated negative selection is that potentially self-reactive $\gamma \delta$ thymocytes are allowed to escape negative selection, undergo extrathymic differentiation, and find sanctuary in the intestinal epithelium. Interestingly, the ability of these potentially self-reactive $\gamma \delta \mathrm{T}$ cells to find sanctuary requires both the intestinal epithelial environment and the extrathymic presence of the self-Ag. The implications of these findings on the development and persistence of autoreactive $\mathrm{T}$ cells in autoimmune disease are discussed.

J. Clin. Invest. 104:1297-1305 (1999).

\section{Introduction}

Immature $\mathrm{T}$ cells that express an autospecific T-cell receptor (TCR) that recognizes an endogenously expressed antigen are eliminated in the thymus through the process of negative selection. This process has been shown in several systems to be an efficient method by which the body prevents potentially harmful autoreactive T cells from developing. During T-cell development, thymocytes that express a specific $V \beta$ TCR that recognizes an endogenously expressed Mls superantigen are eliminated, and are thus virtually absent from the adult thymus $(1,2)$. Similarly, studies on transgenic ( $\mathrm{Tg}$ ) mice have shown that mature $\mathrm{T}$ cells that express a TCR that recognizes an endogenously expressed antigen (Ag) are also deleted (3-7).

Several lines of evidence suggest that, in contrast with the adult thymus, negative selection of autoreactive $\alpha \beta$ and $\gamma \delta$ T cells is either absent or markedly attenuated early in ontogeny. T cells that express V $\beta$ TCRs that recognize an endogenously expressed Mls Ag are found in relatively large numbers in the neonatal thymus, but are virtually absent in the adult thymus (8-10). Similarly, in $\mathrm{HY}, \alpha \beta-\mathrm{T}$ cell Tg mice, Teh et al. demonstrated that Tg $\alpha \beta$ T cells that recognize the male HY antigen are found in almost equal numbers in the thymus of male and female mice at fetal day 16 , but these cells begin to decrease markedly in the male thymus at or near the time of birth (11). Using G8 Tg $\gamma \delta$-TCR mice, Dent et al. demonstrated that $\operatorname{Tg} \gamma \delta \mathrm{T}$ cells, which recognize an endogenously expwressed $\mathrm{TL}^{\mathrm{b}}$ antigen $\left(\mathrm{T} 10^{\mathrm{b}}\right.$ or $\left.\mathrm{T} 22^{\mathrm{b}}\right)$, are found in the neonatal spleen, but are virtually absent in the adult spleen and thymus of $\mathrm{TL}^{\mathrm{b}+}$ mice (12). Although their results suggest that negative selection of $\operatorname{Tg} \gamma \delta \mathrm{T}$ cells is either absent or attenuated in the neonatal thymus, Dent et al. did not examine the neonatal thymus and therefore did not address the possibility that $\operatorname{Tg} \gamma \delta \mathrm{T}$ cells found in the spleen of neonatal $\mathrm{TL}^{\mathrm{b}+}$ mice were derived from an extrathymic pathway (13-16). Nevertheless, these results collectively suggest that the ability of the neonatal thymus to remove autospecific neonatal thymocytes is either absent or severely attenuated.

The fate of these autospecific neonatal thymocytes is an important issue that has not been addressed in the discussed neonatal studies. Presumably, a few cells escape out into the periphery and remain senescent at very low numbers, but most die from negative selection and possibly peripheral deletion. Therefore, it is interesting to note that like the neonatal thymus, the intestinal epithelial lymphocyte (IEL) population appears to be rich in T cells that bear autospecific TCR. The IEL population has been shown to be rich in $\alpha \beta \mathrm{T}$ cells, which express V $\beta$ TCRs that recognize an endogenously expressed Mls Ag (17). Furthermore, studies on $\alpha \beta-$ and $\gamma \delta$-T cell Tg mice, which express a TCR that recognizes endogenously expressed Ag, have shown that the 


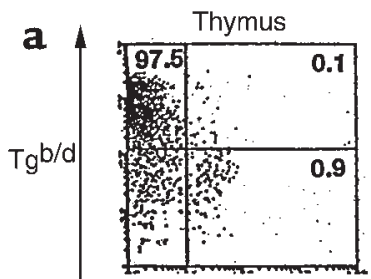

พ

늘

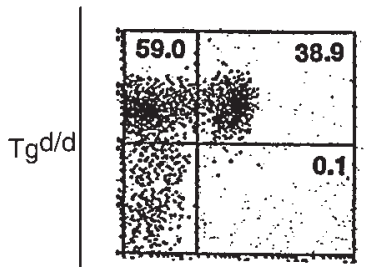

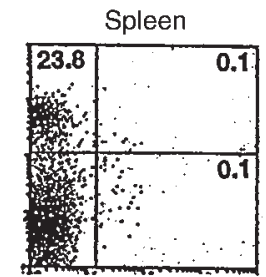

$\mathrm{V} \gamma 2^{+}$

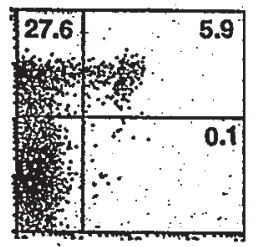

b

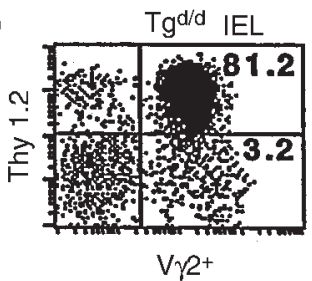

$\mathrm{V} \gamma \mathrm{2}^{+}$

C

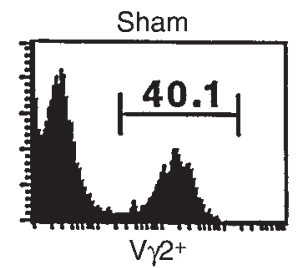

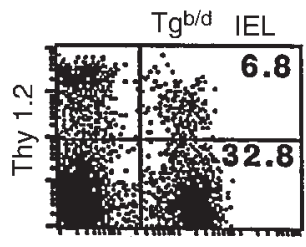

$\mathrm{V} \mathrm{\gamma}^{+}$

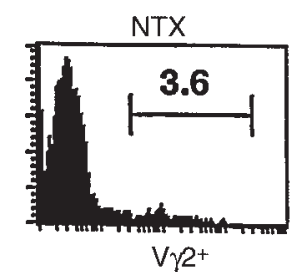

Figure 1

(a) Flow cytometry (FCM) 2-color analysis of thymus and spleen from Tgb/d (top row) and $\mathrm{Tg}$ d/d (bottom row) mice. (b) FCM analysis of IEL from $\mathrm{Tg}^{\mathrm{d} / \mathrm{d}}$ (left) and $\mathrm{Tg} \mathrm{b} / \mathrm{d}$ (right) mice. (c) FCM histogram analysis of IEL from 6-week-old $\mathrm{Tg}^{\mathrm{b} / \mathrm{d}}$ mice that were sham operated (left) and thymectomized (NTX; right) on day 2 of life. Data shown represent 1 of 2 independent experiments.

IEL population is rich in $\mathrm{T}$ cells that express autospecific TCR $(16,18-20)$. However, how these IEL that express autospecific TCR escape negative selection is unclear. Present theory suggests that most IEL that express an autospecific TCR avoid thymic negative selection by developing by an extrathymic pathway (16, $17,21)$. However, the relative contribution of the extrathymic pathway to the development of most IEL is controversial $(22,23)$. Nude mice that are congenitally athymic have virtually no TCR $\alpha \beta$ IEL and have markedly reduced numbers of TCR $\gamma \delta$ IEL compared with normal euthymic mice $(22,24)$. Furthermore, several studies have shown that many IEL, which were originally believed to develop solely through an extrathymic pathway, can also be derived from the fetal/neonatal thymus $(25,26)$.

In this study, we investigated whether there is a direct relationship between the absence or attenuation of negative selection in the neonatal thymus and the abundant number of IEL that express an autospecific TCR. Using G8 $\gamma \delta \mathrm{Tg}$ mice as a model of negative selection of $\gamma \delta \mathrm{T}$ cells, we demonstrate that negative selection is severely attenuated in the neonatal thymus so that up to $40 \%$ of day 2 neonatal thymocytes bear the autospecific $\operatorname{Tg} \gamma \delta$ TCR. Furthermore, a consequence of this attenuated negative selection is that potentially selfreactive $\operatorname{Tg} \gamma \delta$ neonatal thymocytes, which appear to be in the process of undergoing negative selection, are able to escape, differentiate extrathymically, and find sanctuary in intestinal epithelium, where they survive and incease in number. Lastly, we demonstrate that the ability of the intestinal epithelium to serve efficiently as a sanctuary for autospecific $\gamma \delta$ T cells requires, paradoxically, the extrathymic presence of the self-Ag. The implications of these findings on the development of IEL and the development and persistence of autoreactive $T$ cells found in autoimmune disease are discussed.

\section{Methods}

Mice. Transgenic mice with or without the $\mathrm{TL}^{\mathrm{b}} \mathrm{Ag}\left(\mathrm{Tg}^{\mathrm{b} / \mathrm{d}}\right.$ or $\mathrm{Tg} d / \mathrm{d}$, respectively) were generated by breeding a single $\mathrm{G} 8 \mathrm{Tg}^{\mathrm{d} / \mathrm{d}}$ founder male to either C57BL/6 $\left(\mathrm{TL}^{\mathrm{b}+}, \mathrm{H}-2^{\mathrm{b}+}\right)$ or BALB/c $\left(\mathrm{TL}^{\mathrm{d}+}, \mathrm{H}-2^{\mathrm{d}+}\right)$ females, respectively $(3,16,27)$. Time of birth was considered day 0 . All mice, including athymic mice bearing the $\mathrm{TL}^{\mathrm{b}} \mathrm{Ag}\left(\mathrm{TL}^{\mathrm{b}+}, \mathrm{C} 57 \mathrm{BL} / 6 \mathrm{nu} / \mathrm{mu}\right)$ and those not bearing the $\mathrm{TL}^{\mathrm{b}} \mathrm{Ag}\left(\mathrm{TL}^{\mathrm{d}}, \mathrm{BALB} / \mathrm{c} n u / n u\right)$, were obtained from The Jackson Laboratory (Bar Harbor, Maine, USA). All mice were raised under specific pathogen-free conditions in the animal care facility at the La Jolla Institute of Allergy and Immunology.

Cell isolation, flow cytometry analysis, and cell sorting. Isolation of IEL and cells from the thymus, spleen, and lymph node has been described previously (28). IEL described specifically as $\mathrm{Tg} b / \mathrm{d}$ neonatal thymus-derived were isolated from C57BL/ 6 nude mice grafted 6 weeks previously with $\mathrm{Tg} g^{\mathrm{b} / \mathrm{d}}$ day 2 neonatal thymus (described below). Two- or 3-color flow cytometry analysis was performed with a FACScan flow cytometer from Becton Dickinson and Co. (Franklin Lakes, New Jersey, USA). The data were analyzed with the Macintosh CellQuest program. Cell sorting was performed with a FACStar cell sorter from Becton Dickinson and Co.

All antibodies were obtained from PharMingen (San Diego, California, USA) unless otherwise noted. Antibodies and reagents used were as follows: FITC-conjugated and nonconjugated anti-V $\gamma 2$ (UC3-10A6), FITCconjugated and biotin-conjugated anti-TCR $\beta$ (H57-597), PE-conjugated anti-Thy 1.2, biotin-conjugated anti-CD8 $\beta$ (Caltag Laboratories Inc., Burlingame, California, USA), biotin-conjugated anti-H-2 $\mathrm{K}^{\mathrm{d}}$, biotin-conjugated anti-H-2K $\mathrm{K}^{\mathrm{b}}$ PE-conjugated antiCD4, PE-conjugated anti-CD8 $\alpha$, PE-conjugated CD45RB, PE-conjugated anti-HSA, PE-conjugated B220, and streptavidin-PE (GIBCO BRL, Gaithersburg, Maryland, USA). 
Neonatal thymectomy and thymus grafting of nude mice. Neonatal thymectomy was performed on day 2 neonates as described previously $(29,30)$. Grafting of nude mice was performed by placing either 2 lobes of day 2 neonatal thymus or a portion of adult thymus (trimmed to be of similar size to a pair of day 2 neonatal thymuses) under the kidney capsule as described previously (31).

Proliferation assay. Unless otherwise stated, responder cells $\left(2 \times 10^{5}\right)$ were cultured with either plate-bound $\mathrm{mAbs}(3 \mu \mathrm{g} / \mathrm{mL})$ or stimulator cells $\left(2 \times 10^{5}\right.$ irradiated spleen cells) for 36 hours in $100 \mu \mathrm{L}$ RPMI with $10 \%$ FCS, and then pulsed with $1 \mu \mathrm{Ci}$ of hydrogen- 3 for 12 hours before harvest. Assays were performed at day 1 , day 2 , and day 3 , in triplicate.

Cytotoxic assay. The ability of IEL to induce the cytotoxic killing of human Jurkat $\mathrm{T}$ cells (primarily through a Fas-mediated mechanism) has been previously described (32). In brief, Jurkat target cells (106 cells $/ \mathrm{mL}$ ) were labeled with $5 \mathrm{mCi} / \mathrm{mL}\left[{ }^{3} \mathrm{H}\right]$ thymidine for 2 hours. Unincorporated $\left[{ }^{3} \mathrm{H}\right]$ thymidine was removed by 2 washes with HBSS. IEL effector cells were cultured with labeled Jurkat target cells $\left(2 \times 10^{4}\right)$ at various effector target ratios in flat-bottomed, 96well plates that had been previously coated with 3 $\mu \mathrm{g} / \mathrm{mL}$ of anti-V $\gamma 2 \mathrm{mAb}$. After 12 hours, cells were harvested using a Skatron cell harvester, and the quantity of $\left[{ }^{3} \mathrm{H}\right]$ thymidine-labeled unfragmented DNA was cal-

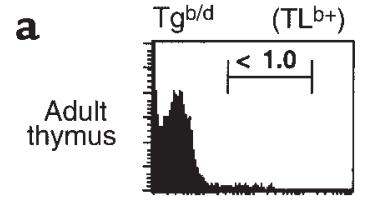

$\mathrm{V} \gamma 2^{+}$

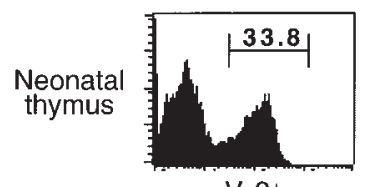

b

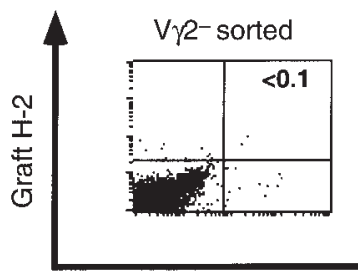

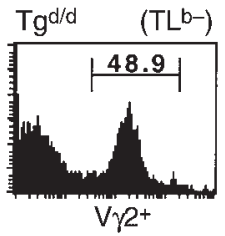

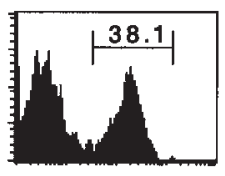

$\mathrm{V} \gamma 2^{+}$

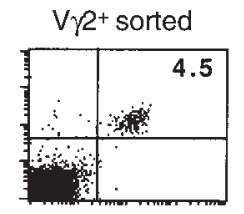

Vy2 culated as follows: \% DNA fragmentation $=100[1-$ (cpm experimental group/cpm control group)] $\pm \mathrm{SD}$. Assays were done in triplicate.

Measurement of IL-2 from $\mathrm{Tg}^{b / d}$ neonatal thymus-derived $V \gamma 2$ IEL. IL-2 was quantified from the supernatant of $2 \times 10^{5}$ IEL cultured with stimulator cells $\left(2 \times 10^{5}\right.$ irradiated $\mathrm{TL}^{\mathrm{b}+}$ spleen cells) for 48 hours in $200 \mu \mathrm{L}$ of RPMI and $10 \%$ FCS media, using a murine IL-2 ELISA kit (Endogen Inc., Woburn, Massachusetts, USA), following the manufacturer's instructions.

\section{Results}

$\gamma \delta$ T cells expressing autospecific TCR are deleted in the adult thymus but are found abundantly in the IEL population. In G8 $\gamma \delta$-TCR Tg mice, Tg $\gamma \delta$ T cells express the $V \gamma 2^{+}$TCR that recognizes the $\mathrm{T} 10^{\mathrm{b}}$ or $\mathrm{T} 22^{\mathrm{b}}$ gene product of the nonclassical MHC class I TLregion $(33,34)$. Thus, in Tg mice with an $\mathrm{H}-2^{\mathrm{d}+}$ background $\left(\mathrm{Tg}^{\mathrm{d} / \mathrm{d}}\right)$, neither $\mathrm{T} 10^{\mathrm{b}}$ nor $\mathrm{T} 22^{\mathrm{b}}$ is present $\left(\mathrm{TL}^{\mathrm{b}-}\right)$, and thus $V \gamma 2^{+} \mathrm{T}$ cells are found in very high numbers in the thymus, spleen, and lymph node (Figure 1a and data not shown). However, in $\mathrm{Tg}$ mice with an $\mathrm{H}-2^{\mathrm{b}+}$ background $\left(\mathrm{Tg}^{\mathrm{b} / \mathrm{d}}\right), \mathrm{T}_{10} \mathrm{~b}$ or $\mathrm{T} 22^{\mathrm{b}}$ is present $\left(\mathrm{TL}^{\mathrm{b}+}\right)$; in the adult mice, $\mathrm{V} \gamma 2^{+} \mathrm{T}$ cells are deleted and thus virtually absent in the thymus, spleen, and lymph node (Figure $1 \mathrm{a}$ and data not shown). The absence of $\mathrm{V} \gamma 2^{+} \mathrm{T}$ cells in the spleen and lymph node of $\mathrm{Tg}^{\mathrm{b} / \mathrm{d}}$ mice reflects either efficient negative selection of $\mathrm{V} \gamma 2^{+}$thymocytes, or (possibly) peripheral deletion of the few $V \gamma 2^{+}$thymocytes that escape negative selection in the $\mathrm{Tg}^{\mathrm{b} / \mathrm{d}}$ thymus. In contrast, $\gamma \delta \mathrm{T}$ cells found in the IEL population appear to be an exception (27). The virtual absence of $\mathrm{V} \gamma 2^{+} \mathrm{T}$ cells in the thymus and periphery of $\mathrm{Tg}^{\mathrm{b} / \mathrm{d}}$ mice contrasts profoundly with the abundant number of $\mathrm{V} \gamma 2^{+} \mathrm{T}$ cells found in the IEL population in both $\mathrm{Tg}^{\mathrm{d} / \mathrm{d}}$ and $\mathrm{Tg}^{\mathrm{b} / \mathrm{d}}$ mice (Figure $1 \mathrm{~b}$ ). To explain this paradox, present theory suggests that most $\mathrm{Tg} / \mathrm{d} / \mathrm{V} 2^{+}$ IEL are derived from an extrathymic pathway (16).

The majority of $\mathrm{Tg}^{b / d} V \gamma 2^{+}$IEL are thymus dependent. Instead of assuming that $\mathrm{Tg} / \mathrm{d} V \gamma 2^{+}$IEL are derived from an extrathymic pathway, we entertained the possibility that the development of $\mathrm{Tg}^{\mathrm{b} / \mathrm{d}} \mathrm{V} \gamma 2^{+}$IEL was dependent on the thymus. Therefore, we thymectomized $\mathrm{Tg} / \mathrm{d}$ mice on neonatal day 2 and examined the IEL population after 6 weeks. Figure 1c demonstrates that neonatal thymectomy resulted in a nearly complete depletion of $\mathrm{V} \gamma 2^{+}$IEL in adult $\mathrm{Tg}^{\mathrm{b} / \mathrm{d}}$ mice, suggesting that development of a vast majority of $\mathrm{V} \gamma 2^{+}$IEL in $\mathrm{Tg}^{\mathrm{b} / \mathrm{d}}$ mice is dependent on the thymus. In addition, examination of the IEL phenotype of neonatal thymectomy $\mathrm{Tg}^{\mathrm{b} / \mathrm{d}}$ mice revealed that there were also very few TCR $\alpha \beta$ IEL (less than 5\%, data not shown). Overall, these results are consistent with our previous observation that neonatal thymectomy results in the depletion of most TCR $\alpha \beta$ IEL and TCR $\gamma \delta$ IEL (22).

$V \gamma 2^{+}$thymocytes are increased in the neonatal $\mathrm{Tg}^{b / d}$ thymus. Neonatal thymectomy results suggest that most $\mathrm{Tg}^{\mathrm{b} / \mathrm{d}}$ $\mathrm{V} \gamma 2^{+}$IEL are derived from the thymus. However, it is unlikely that the adult $\mathrm{Tg}^{\mathrm{b} / \mathrm{d}}$ thymus is a major source of $\mathrm{Tg} / \mathrm{d} V \gamma 2^{+}$IEL, because $V \gamma 2^{+}$thymocytes are virtually 


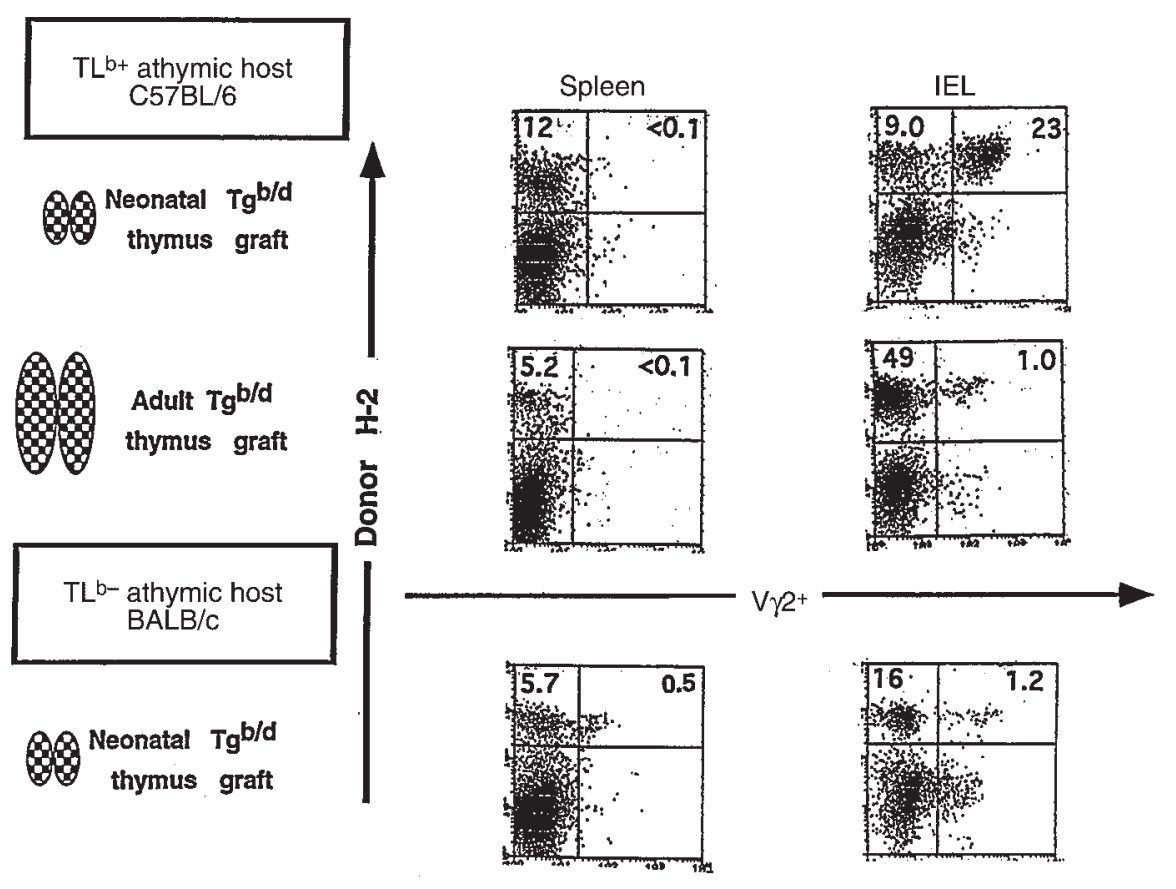

\section{Figure 3}

Efficient homing of $\mathrm{Tg} \mathrm{b} / \mathrm{d} \mathrm{V} \gamma 2^{+}$neonatal thymocytes to the intestinal epithelium requires the extrathymic presence of the $\mathrm{TL}^{\mathrm{b}} \mathrm{Ag}$. FCM analysis of IEL and spleen cells from (top row) athymic C57BL/6 (self-Ag $\mathrm{TL}^{\mathrm{b}+}$ ) mice and (bottom row) athymic BALB/c $\left(\mathrm{TL}^{\mathrm{d}+}\right)$ mice that were grafted 6 weeks previously with the $T g^{\mathrm{b} / \mathrm{d}}$ (day 2) neonatal thymus. (middle row) FCM analysis of IEL and spleen cells from athymic C57BL/6 (self-Ag TL $\mathrm{L}^{\mathrm{b}+}$ ) mice that were grafted with the $\mathrm{Tg}^{\mathrm{b} / \mathrm{d}}$ (6-weekold) adult thymus. Donor $\mathrm{H}-2^{+}$cells represent cells derived from the neonatal thymus graft as determined by the appropriate anti- $\mathrm{H}-2 \mathrm{~K}$ mAb (anti- $\mathrm{H}-2 \mathrm{~K}^{\mathrm{b}}$ or anti-H-2Kd). Data shown represent 1 of 3 independent experiments. absent in this organ (Figure 1a). Therefore we examined the $\mathrm{Tg}$ b/d neonatal thymus as a potential source of $\mathrm{Tg}^{\mathrm{b} / \mathrm{d}}$ $\mathrm{V} \gamma 2^{+}$IEL. Unlike $\mathrm{Tg}^{\mathrm{b} / \mathrm{d}}$ adult thymocytes, a large percentage of $\mathrm{Tg}^{\mathrm{b} / \mathrm{d}}$ neonatal thymocytes express the $\mathrm{V} \gamma 2^{+}$ TCR (Figure $2 \mathrm{a}$ ). The percentage of $\mathrm{Tg}^{\mathrm{b} / \mathrm{d}} \mathrm{V} \gamma 2^{+}$thymocytes varied considerably among the thymuses (ranging between $7 \%$ and $40 \%$, data not shown), and persisted at increased levels up to 7 days of age. By 2 weeks of age, the percentage of $\mathrm{V} \gamma 2^{+}$thymocytes became severely diminished and similar to the level found in adult $\mathrm{Tg}^{\mathrm{b} / \mathrm{d}}$ thymus (data not shown).

$\mathrm{Tg}^{b / d} V \gamma^{+}$neonatal thymocytes can give rise to $\mathrm{Tg}^{b / d} V \gamma 2^{+} \mathrm{IEL}$. Some compelling evidence suggests that the murine intestinal epithelium is a site for extrathymic T-cell development $(13,19,21,23,35)$. Hence, $\mathrm{Tg}^{\mathrm{b} / \mathrm{d}} \mathrm{V} \gamma 2^{+}$neonatal thymocytes may not migrate to the intestinal epithelium, but $\mathrm{Tg}^{\mathrm{b} / \mathrm{d}} \mathrm{V} \gamma 2$ - neonatal thymocytes could migrate to the intestinal epithelium and develop extrathymically into $\mathrm{Tg}^{\mathrm{b} / \mathrm{d}}$ $\mathrm{V} \gamma 2^{+}$IEL. To address this question, flow cytometry-purified $\mathrm{Tg}^{\mathrm{b} / \mathrm{d}} \mathrm{V} 2^{+}$or $\mathrm{Tg}^{\mathrm{b} / \mathrm{d}} \mathrm{V} \gamma 2^{-}$thymocytes were injected into congenitally athymic $\mathrm{TL}^{\mathrm{b}+}$ nude $\mathrm{C} 57 \mathrm{BL} / 6$ hosts. Figure $2 \mathrm{~b}$ demonstrates that $\mathrm{Tg}^{\mathrm{b} / \mathrm{d}} V \gamma 2^{+}$, but not $\mathrm{Tg}^{\mathrm{b} / \mathrm{d}} \mathrm{V} \gamma 2^{-}$neonatal thymocytes, are capable of generating $\mathrm{V} \gamma 2^{+}$IEL. This suggests that it is unlikely that $\mathrm{Tg} b / \mathrm{d} V \gamma 2^{-}$neonatal thymocytes migrate to the intestinal epithelium and differentiate into $V \gamma 2^{+}$IEL. Furthermore, examination of lymph node and spleen of $\mathrm{TL}^{\mathrm{b}+}$ nude mice injected with $\mathrm{Tg}^{\mathrm{b} / \mathrm{d}} \mathrm{V} \mathrm{2}^{+}$ neonatal thymocytes revealed no detectable presence of $\mathrm{Tg} V \gamma 2^{+} \mathrm{T}$ cells (data not shown). This suggests that $\mathrm{Tg} / \mathrm{d}$ $\mathrm{V} \gamma 2^{+}$neonatal thymocytes are predestined to either migrate to the intestinal epithelium or undergo peripheral deletion in the spleen and lymph node.

Efficient migration of $\mathrm{Tg}^{b / d} V \gamma 2^{+}$neonatal thymocytes to the intestinal epithelium requires the extrathymic presence of the $T^{b}$ $\mathrm{Ag}$. To explore the fate of $\mathrm{Tg}^{\mathrm{b} / \mathrm{d}} \mathrm{V} \gamma 2^{+}$neonatal thymocytes in a model that mimics normal ontogeny as closely as possible, we grafted $\mathrm{Tg} / \mathrm{d}\left(\mathrm{H}-2^{\mathrm{b}+/ \mathrm{d}+}\right)$ neonatal thymus into $\mathrm{TL}^{\mathrm{b}+}\left(\mathrm{H}-2^{\mathrm{b}+}\right)$ adult nude mice. In this model, cells derived from the thymus graft (donor) can be distinguished from cells derived from the nude hosts by a mAb that specifically recognizes the donor-specific class $\mathrm{I} \mathrm{H}-2 \mathrm{~K}^{\mathrm{d}}$ molecule (shown as donor $\mathrm{H}-2^{+}$in Figure 3). As shown in Figure 3 (upper row), grafting of the $\mathrm{Tg} / \mathrm{d}$ neonatal thymus into a $\mathrm{TL}^{\mathrm{b}+}$ adult nude host readily generated graft-derived cells in both the spleen and IEL populations. Not surprisingly, the $\mathrm{Tg}^{\mathrm{b} / \mathrm{d}}$ neonatal thymus failed to generate $\mathrm{V} \gamma 2^{+} \mathrm{T}$ cells in the spleen of the nude $\mathrm{TL}^{\mathrm{b}+}$ host. Presumably, this is either because $\mathrm{Tg}^{\mathrm{b} / \mathrm{d}} \mathrm{V} \gamma 2^{+}$neonatal thymocytes cannot escape negative selection or they undergo deletion after escaping into the periphery. In contrast, the Tgb/d neonatal thymus was very efficient at generating $V \gamma 2^{+}$IEL when grafted into $\mathrm{TL}^{\mathrm{b}+}$ nude hosts. Phenotypic studies of the $\mathrm{V} \gamma 2^{+}$IEL generated by the $\mathrm{Tg}^{\mathrm{b} / \mathrm{d}}$ neonatal thymus graft in $\mathrm{TL}^{\mathrm{b}+}$ nude hosts suggests that they are mature (HSA-) and bear a phenotype that resembles the $V \gamma 2^{+}$IEL found normally in $\mathrm{Tg}^{\mathrm{b} / \mathrm{d}}$ mice $\left(\mathrm{CD} 8 \alpha^{+}\right.$, Thy $1^{-}$, and $\left.\mathrm{B} 220^{+}\right)$, rather than the $\mathrm{V} \gamma 2^{+}$IEL found in $\mathrm{Tg}^{\mathrm{d} / \mathrm{d}}$ mice (CD8-, Thy $1^{+}$, B220-) (16 and data not shown). In addition, the functional properties of $\mathrm{Tg} / \mathrm{d}$ neonatal thymus graft-derived $\mathrm{V} \gamma 2^{+}$IEL appear to be very similar to those reported for $\mathrm{V} \gamma 2^{+}$IEL found in $\mathrm{Tg}{ }^{\mathrm{b} / \mathrm{d}}$ mice (27). Upon anti-V $\gamma 2 \mathrm{TCR}$ stimulation or culture with irradiated $\mathrm{TL}^{\mathrm{b}+}$ spleen cells as stimulators, $\mathrm{Tg}^{\mathrm{b} / \mathrm{d}}$ neonatal thymus graft-derived $\mathrm{V} \gamma 2^{+} \mathrm{IEL}$ proliferated poorly and produced nearly undetectable levels of IL-2 (data not shown). Furthermore, unlike V $\gamma 2^{+}$ IEL from $T g^{d / d}$ mice, which readily mediated the cytotoxic killing of Jurkat $T$ cells upon stimulation with anti-V $\gamma 2$ $\mathrm{mAb}$, both $\mathrm{Tg}^{\mathrm{b} / \mathrm{d}}$ neonatal thymus graft-derived $\mathrm{V} \gamma 2^{+} \mathrm{IEL}$ and $V \gamma 2^{+}$IEL from $\mathrm{Tg}^{\mathrm{b} / \mathrm{d}}$ mice exhibited very weak cytotoxicity against human Jurkat T cells (data not shown). 
To determine whether the ability of $\mathrm{Tg}^{\mathrm{b} / \mathrm{d}} \mathrm{V} \gamma 2^{+}$neonatal thymocytes to escape negative selection and migrate to the intestinal epithelium is a consequence of absent or attenuated negative selection during the neonatal period, nude $\mathrm{TL}^{\mathrm{b}+}$ hosts were grafted with $\mathrm{Tg}^{\mathrm{b} / \mathrm{d}}$ adult thymus, in which the negative selection of $\mathrm{Tg} V \gamma 2^{+}$is almost complete (Figures 1 and 2). Figure 3 (middle row) demonstrates that the adult $\mathrm{Tg}^{\mathrm{b} / \mathrm{d}}$ thymus generated graft-derived cells in both the IEL and spleen populations of nude $\mathrm{TL}^{\mathrm{b}+}$ hosts, but relatively few were $\mathrm{V} \gamma 2^{+}$ $\mathrm{T}$ cells. Although it is possible that the adult Tg thymus simply could not generate $V \gamma 2^{+}$IEL, this is unlikely because grafting of Tgd/d adult thymus into $\mathrm{TL}^{\mathrm{d}+} \mathrm{BALB} / \mathrm{c}$ nude mice readily generated $V \gamma 2+$ IEL (data not shown). Overall, these results suggest that it is the absence or attenuation of negative selection during neonatal development that allows $\mathrm{Tg}^{\mathrm{b} / \mathrm{d}}$ neonatal thymus to generate $\mathrm{V} \gamma 2^{+}$IEL in $\mathrm{TL}^{\mathrm{b}+}$ nude hosts.

Next, we examined whether the extrathymic presence of the $\mathrm{TL}^{\mathrm{b}} \mathrm{Ag}$ was required for the generation of $\mathrm{V} \gamma 2^{+}$ IEL in the nude host by grafting the $\mathrm{Tg}^{\mathrm{b} / \mathrm{d}}$ neonatal thymus into $\mathrm{TL}^{\mathrm{d}+} \mathrm{BALB} / \mathrm{c}$ nude mice, which do not bear the TL ${ }^{b} \mathrm{Ag}$. In this model, cells derived from the thymus graft (donor) can be distinguished from cells derived from the nude host by a mAb that specifically recognizes the donor-specific class I $\mathrm{H}-2 \mathrm{~K}^{\mathrm{b}}$ molecule (shown as donor $\mathrm{H}_{-} 2^{+}$in Figure 3). Although $\mathrm{Tg}^{\mathrm{b} / \mathrm{d}}$ neonatal thymus readily generated $T$ cells in the spleen and IEL populations of $\mathrm{TL}^{\mathrm{d}+}$ hosts, only a relatively small percentage of those $\mathrm{T}$ cells was $\mathrm{V} \gamma 2^{+}$(Figure 3, bottom row). Although the total percentage of $\mathrm{Tg}^{\mathrm{b} / \mathrm{d}}$ neonatal
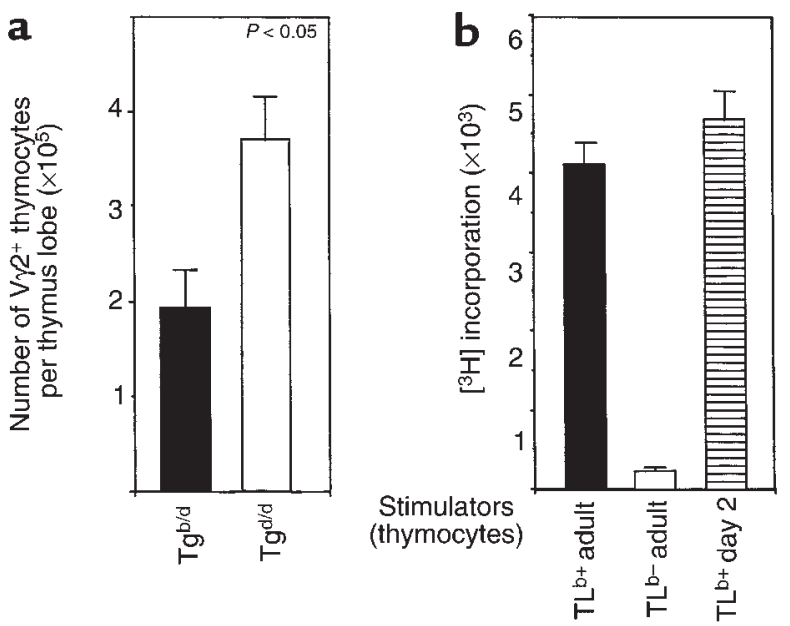

Figure 4

(a) Negative selection of $\mathrm{Tg} / \mathrm{d} \mathrm{V} \gamma 2^{+}$neonatal thymocytes is attenuated in day 2 neonatal thymus. The total number of $\mathrm{V} \gamma 2^{+}$neonatal thymocytes is reduced by approximately $50 \%$ in $\mathrm{Tg} / \mathrm{d}$ neonatal thymus when compared with $\mathrm{Tg} / \mathrm{d}$ neonatal thymus. Data are shown as the mean of more than 20 neonatal thymus lobes examined separately for each group. (b) The TLb self-Ag is functionally present in the neonatal $\mathrm{Tg}^{\mathrm{b} / \mathrm{d}}$ thymus. To test for the functional presence of the $\mathrm{TL}^{\mathrm{b}} \mathrm{Ag}, 10^{5}$ irradiated stimulator cells were cultured with adult $T \mathrm{~g} d / \mathrm{d}$ thymocytes that were sorted to remove TCR $\beta$ cells to avoid a nonspecific allogeneic response. Data shown represent 1 of 2 independent experiments. thymus graft-derived $\mathrm{V} \gamma 2^{+} \mathrm{T}$ cells found in the spleen and IEL of athymic TL ${ }^{d+}$ hosts was very small, it constituted almost $10 \%$ of the total number of $\mathrm{Tg}^{\mathrm{b} / \mathrm{d}}$ neonatal thymus graft-derived $\mathrm{T}$ cells. This suggests that in the absence of the extrathymic $\mathrm{TL}^{\mathrm{b}} \mathrm{Ag}$, autospecific $\mathrm{Tg}^{\mathrm{b} / \mathrm{d}}$ $\mathrm{V} \gamma 2^{+}$neonatal thymocytes are capable of escaping negative selection and surviving in both the spleen and the intestinal epithelium at very low levels. However, as shown in Figure 3 (top row), when the $\mathrm{Tg}^{\mathrm{b} / \mathrm{d}}$ neonatal thymus was grafted into $\mathrm{TL}^{\mathrm{b}+}$ nude mice, the extrathymic presence of the $\mathrm{TL}^{\mathrm{b}} \mathrm{Ag}$ appeared to induce peripheral deletion of $\mathrm{Tg}^{\mathrm{b} / \mathrm{d}} \mathrm{V} \gamma 2^{+} \mathrm{T}$ cells in the spleen, and paradoxically, survival and increase in number of $\mathrm{Tg}^{\mathrm{b} / \mathrm{d}} \mathrm{V} \gamma 2^{+} \mathrm{T}$ cells in the intestinal epithelium. Overall, these results suggest that the intestinal epithelium of $\mathrm{TL}^{\mathrm{b}+}$ mice, but not $\mathrm{TL}^{\mathrm{d}+}$ mice, can serve as a sanctuary for $\mathrm{Tg}^{\mathrm{b} / \mathrm{d}} \mathrm{V} \gamma 2^{+}$neonatal thymocytes that have escaped negative selection and peripheral deletion.

Negative selection of $\mathrm{V}^{2} 2^{+}$thymocytes is present but attenuated in the neonatal $\mathrm{Tg}^{\mathrm{b} / \mathrm{d}}$ thymus. If neonatal $\mathrm{Tg}^{\mathrm{b} / \mathrm{d}}$ thymus is a major source of $\mathrm{Tg}^{\mathrm{b} / \mathrm{d}} \mathrm{V} \gamma 2^{+} \mathrm{IEL}$, as suggested by our results, then an important question is whether negative selection of autospecific $\mathrm{Tg} / \mathrm{d} \mathrm{V} \gamma 2+\mathrm{T}$ cells is attenuated or simply absent in the neonatal thymus. As shown in Figure $4 \mathrm{a}$, the total number of $\mathrm{V} \gamma 2^{+}$thymocytes in the $\mathrm{Tg} \mathrm{b} / \mathrm{d}$ neonatal thymus was reduced by $50 \%$ when compared with $\mathrm{Tg}^{\mathrm{d} / \mathrm{d}}$ neonatal thymus, suggesting that some form of negative selection is present in the neonatal $\mathrm{Tg}{ }^{\mathrm{b} / \mathrm{d}}$ thymus. However, because there was a decrease of more than $95 \%$ in the total number of $\mathrm{V} \gamma 2^{+}$thymocytes found in the adult $\mathrm{Tg}^{\mathrm{b} / \mathrm{d}}$ thymus compared with adult $\operatorname{Tg}^{\mathrm{d} / \mathrm{d}}$ thymus (data not shown), these results also suggest that negative selection of $V \gamma 2^{+}$thymocytes in the neonatal $\mathrm{Tg}^{\mathrm{b} / \mathrm{d}}$ thymus is present, but attenuated.

$\mathrm{TL}^{b} \mathrm{Ag}$ is present in the $\mathrm{Tg}^{b / d}$ neonatal thymus. We next explored the question of whether the attenuated level of negative selection in the $\mathrm{Tg}^{\mathrm{b} / \mathrm{d}}$ neonatal thymus may simply be the result of lower $\mathrm{TL}^{\mathrm{b}} \mathrm{Ag}$ expression in the neonatal thymus. To test this hypothesis, we looked for the functional presence of the $\mathrm{TL}^{\mathrm{b}} \mathrm{Ag}$ by testing the ability of irradiated $\mathrm{Tg}^{\mathrm{b} / \mathrm{d}}$ neonatal thymocytes to induce the proliferation of $\mathrm{Tg}^{\mathrm{d} / \mathrm{d}} \mathrm{V} \gamma 2^{+}$adult thymocytes, which should specifically recognize the $\mathrm{TL}^{\mathrm{b}} \mathrm{Ag}$. To avoid an allogeneic response, we sorted and removed TCR $\beta$ thymocytes before culturing with irradiated $\mathrm{Tg}^{\mathrm{b} / \mathrm{d}}$ neonatal thymocytes. Hence, any proliferative response should be the result of $\mathrm{Tg}^{\mathrm{d} / \mathrm{d}} \mathrm{V} \gamma 2^{+}$thymocytes recognizing the $\mathrm{TL}^{\mathrm{b}} \mathrm{Ag}$. Figure $4 \mathrm{~b}$ demonstrates that the $\mathrm{TL}^{\mathrm{b}} \mathrm{Ag}$ is functionally present in day 2 neonatal $\mathrm{Tg}^{\mathrm{b} / \mathrm{d}}$ thymus at levels equal to if not higher than those found in the adult $\mathrm{Tg}^{\mathrm{b} / \mathrm{d}}$ thymus. As expected, no functional $\mathrm{TL}^{\mathrm{b}} \mathrm{Ag}$ was detectable in the $\mathrm{Tg} \mathrm{d} / \mathrm{d}$ adult thymus. Overall, these results suggest that the attenuation of negative selection of $\mathrm{Tgb} / \mathrm{d} V \gamma 2^{+}$neonatal thymocytes is unlikely to be due to a lower level of TL ${ }^{\mathrm{b}} \mathrm{Ag}$ expression in the $\mathrm{Tg}^{\mathrm{b} / \mathrm{d}}$ neonatal thymus.

Phenotypic examination suggests that $\mathrm{Tg}^{b / d} V \gamma^{+}$neonatal thymocytes have encountered the $T L^{b} \mathrm{Ag}$ at an immature stage in development. If negative selection of $\mathrm{Tg} / \mathrm{d} V \gamma 2^{+}$neona- 

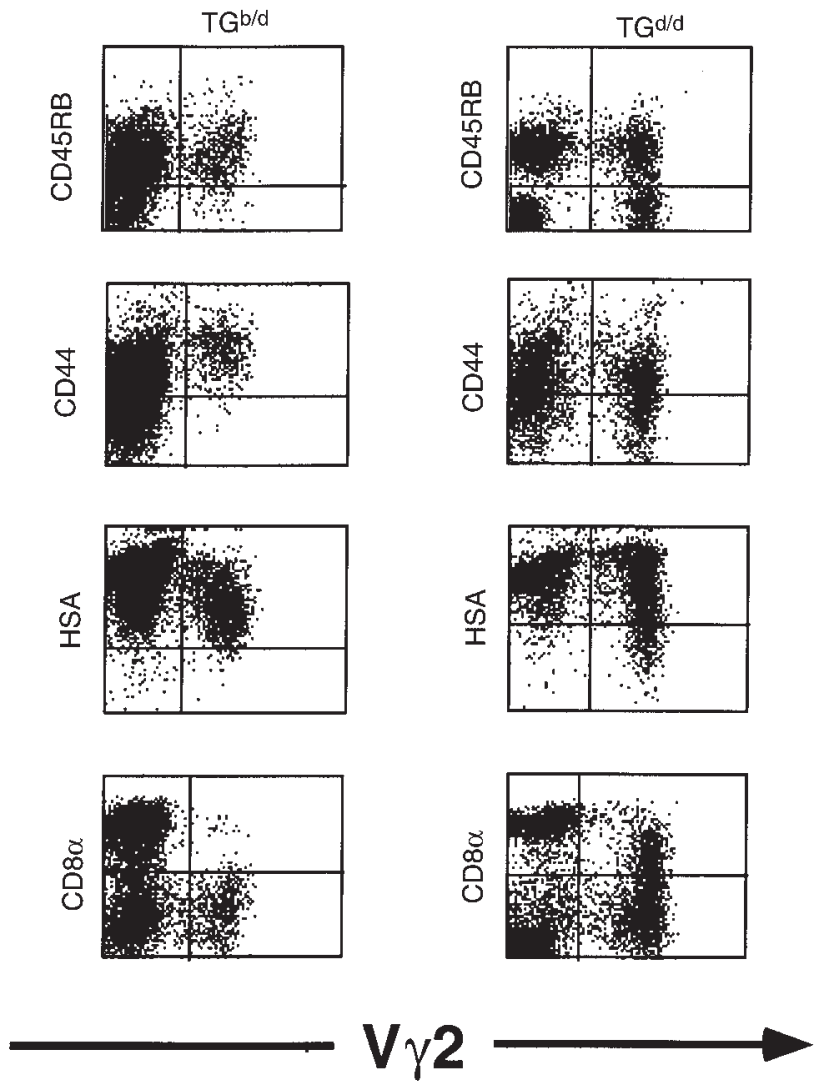

Figure 5

FCM analysis of neonatal $\mathrm{Tg}^{\mathrm{b} / \mathrm{d}}$ (left) and $\mathrm{Tg}$ d/d (right) thymocytes for markers of T-cell development and activation. Data shown represent 1 of 3 independent experiments.

tal thymocytes is partially functional and the $\mathrm{TL}^{\mathrm{b}} \mathrm{Ag}$ is present in the neonatal thymus, we rationalized that there should be some evidence that $\mathrm{V} \gamma 2^{+} \mathrm{Tg}^{\mathrm{b} / \mathrm{d}}$ neonatal thymocytes have encountered the TL self-Ag. Comparison of $\mathrm{Tg}^{\mathrm{b} / \mathrm{d}}$ and $\mathrm{Tg}^{\mathrm{d} / \mathrm{d}} \mathrm{V} \gamma 2^{+}$neonatal thymocytes for several phenotypic markers of differentiation and activation revealed that $\mathrm{Tg}^{\mathrm{d} / \mathrm{d}} \mathrm{V} \gamma 2^{+}$neonatal thymocytes are comprised of a heterogeneous population expressing various levels of CD8 $\alpha, C D 45 R B, C D 44$, and HSA. In contrast, $\mathrm{Tg}^{\mathrm{b} / \mathrm{d}} \mathrm{V} \gamma 2^{+}$neonatal thymocytes are a relatively homogenous population and are uniformly CD8-, $\mathrm{CD}_{5} \mathrm{RB}^{\mathrm{hi}}$, CD44hi, and $\mathrm{HSA}^{+}$(Figure 5). Because $\mathrm{Tg}^{\mathrm{b} / \mathrm{d}}$ $\mathrm{V} \gamma 2^{+}$neonatal thymocytes, but not $\mathrm{Tg}^{\mathrm{d} / \mathrm{d}} \mathrm{V} 2^{+}$neonatal thymocytes, are virtually all positive for CD44 and HSA, which have been reported to be markers of activation and thymocyte immaturity (36-39), these results suggest that $\mathrm{Tg}^{\mathrm{b} / \mathrm{d}} \mathrm{V} \gamma 2^{+}$neonatal thymocytes have been activated (presumably by the $\mathrm{TL}^{\mathrm{b}} \mathrm{Ag}$ ), but are also blocked at an immature stage of development. Furthermore, closer phenotypic examination revealed that $\mathrm{Tg} b / \mathrm{d} V 2^{+}$neonatal thymocytes express significantly lower levels of Thy 1 and $V \gamma^{2}$ TCR than do naive $\mathrm{Tg}^{\mathrm{d} / \mathrm{d}}$ $\mathrm{V} \gamma 2^{+}$neonatal thymocytes (Figure 6a). Therefore, we tested the hypothesis that lower levels of Thy 1 and TCR expression are markers of $\mathrm{TL}^{\mathrm{b}} \mathrm{Ag}$ recognition by examining naive $T g^{\mathrm{d} / \mathrm{d}} V \gamma 2^{+}$neonatal thymocytes before and after activation in vitro with either anti-V $\gamma 2 \mathrm{mAb}$ or irradiated $\mathrm{TL}^{\mathrm{b}+} \mathrm{Tg}^{\mathrm{b} / \mathrm{d}}$ spleen cells. Figure $6 \mathrm{~b}$ demonstrates that, consistent with our hypothesis, activation of $\mathrm{Tg}^{\mathrm{d} / \mathrm{d}} \mathrm{V} \gamma 2^{+}$neonatal thymocytes resulted in lower levels of Thy 1 and $V \gamma 2$ TCR expression.

\section{Discussion}

Using G8 $\gamma \delta \mathrm{Tg}$ mice, we have demonstrated that the negative selection of $\gamma \delta \mathrm{T}$ cells bearing an autospecific TCR is markedly attenuated in the neonatal thymus. A consequence of this attenuated negative selection is that potentially self-reactive thymocytes are allowed to escape negative selection, and migrate to the intestinal epithelium where they survive and increase in number. Although several studies have shown that negative selection is either absent or attenuated in the neonatal thymus, our study is the first to demonstrate that the fate of autospecific neonatal thymocytes can be other than death by negative selection. What makes our results intriguing is that we have also demonstrated that despite our autospecific neonatal $\gamma \delta$ thymocytes appearing to be in the process of undergoing negative selection, the intestinal epithelium somehow serves as a sanctuary for these autospecific neonatal thymocytes. Lessons learned from studying this pathway are relevant to our understanding of how autoreactive $T$ cells are allowed to develop and persist in autoimmune disease. It is worth noting that most studies that have addressed the fate of autospecific $T$ cells have done so by transferring naive autospecific $\mathrm{T}$ cells into a host that expresses an Ag that is recognized by the transferred autospecific T cells. These studies, however, may not provide accurate models for studying the fate of autoreactive $T$ cells in autoimmune disease, because they assume that autoreactive $T$ cells are naive and have never encountered the self-Ag in development (i.e., negative selection). Our study addresses this issue and specifically examines the fate of autospecific $T$ cells that have truly escaped functional negative selection.

From our model, 3 criteria appear to be required for autospecific thymocytes to escape negative selection and find sanctuary. The first criterion is that negative selection must be attenuated so that thymocytes expressing an autospecific TCR are allowed to escape negative selection. In our model, the neonatal period provides a brief window of time during which autospecific thymocytes can escape negative selection. It would be interesting to speculate whether stress or infection (which are both associated with autoimmune disease) can induce a similar phenomenon. The second criterion is that the self-Ag must be present extrathymically. Grafting of the $\mathrm{Tg}$ b/d neonatal thymus generated a large number of $\mathrm{V} \gamma 2^{+} \mathrm{T}$ cells in the intestinal epithelium of only $\mathrm{Ag}^{+} \mathrm{TL}^{\mathrm{b}+}$ hosts, but not in $\mathrm{Ag}^{-} \mathrm{TL}^{\mathrm{d}+}$ hosts (Figure 3). This criterion is puzzling, because our results suggest that $\mathrm{Tg}^{\mathrm{b} / \mathrm{d}} \mathrm{V} \gamma^{+}$neonatal thymocytes have already encountered the $\mathrm{TL}^{\mathrm{b}} \mathrm{Ag}$ and are rendered unresponsive to TCR stimulation (data not shown). The third criterion appears to be the environment. In our model, 
grafting of the $\mathrm{Tg}^{\mathrm{b} / \mathrm{d}}$ neonatal thymus into $\mathrm{TL}^{\mathrm{b}+}$ null hosts generated a large population of $\mathrm{V} \gamma 2^{+} \mathrm{T}$ cells only in the intestinal epithelium and not elsewhere (Figure 3 and data not shown). This suggests that the intestinal epithelium provides a unique environment that allows the survival and expansion of autospecific neonatal thymocytes. The nature of this environment, however, is not presently known.

We also attempted to determine whether encountering the $\mathrm{TL}^{\mathrm{b}} \mathrm{Ag}$ intrathymically early in ontogeny gives $\mathrm{V} \gamma 2^{+}$neonatal thymocytes a selective advantage in their ability to migrate to the intestinal epithelium of $\mathrm{TL}^{\mathrm{b}+}$ nude mice. Unfortunately, neither injection of $\mathrm{Tg} / \mathrm{d}$ $\mathrm{V} \gamma 2^{+}$thymocytes nor grafting of the Tgd/d neonatal thymus into $\mathrm{TL}^{\mathrm{b}+}$ nude mice generated any graft-derived cells in the IEL, spleen, or lymph node populations of the nude host (data not shown). This is probably because host natural killer cells reject thymus graftderived $T$ cells in a fully allogeneic model. On the other hand, grafting of $\mathrm{Tg}^{\mathrm{d} / \mathrm{d}}$ neonatal thymus into a syngeneic $\mathrm{TL}^{\mathrm{d}+}$ nude host readily generated $\mathrm{Tg} \mathrm{V} \gamma 2^{+}$IEL (data not shown). This suggests that, at the very least, encountering the TL ${ }^{\mathrm{b}}$ self-Ag in the neonatal thymus is not necessary for $\mathrm{Tg} \mathrm{V} \gamma 2^{+}$neonatal thymocytes to migrate to the intestinal epithelium.

An important question is whether our observations are also applicable to autospecific neonatal $\alpha \beta$ thymocytes. Studies on $\alpha \beta$ T cells, which recognize an endogenously expressed Mls Ag, and $\operatorname{Tg} \alpha \beta$ T cells, which recognize the male HY Ag, have shown that autospecific $\alpha \beta$ $\mathrm{T}$ cells are found in relatively large numbers in both the neonatal thymus and IEL populations $(8-11,17,20)$. These findings suggest that reminiscent of our observations regarding autospecific neonatal $\gamma \delta$ thymocytes, the intestinal epithelium can also serve as a sanctuary for autospecific neonatal $\alpha \beta$ thymocytes. However, whether these thymocytes can migrate to the intestinal epithelium and find sanctuary has not been directly demonstrated and is presently under investigation.

We have shown that $T g^{\mathrm{b} / \mathrm{d}} V \gamma 2^{+}$neonatal thymocytes can give rise to $\mathrm{Tg} / \mathrm{d} \mathrm{V} \gamma 2^{+}$IEL. Interestingly, the phenotypes of these 2 lineage-related populations are markedly different. For example, most $\mathrm{Tg} / \mathrm{d} \mathrm{V} \gamma 2^{+}$neonatal thymocytes are $\mathrm{HSA}^{+}, \mathrm{B} 220^{-}, \mathrm{CD} 8^{-}$, Thy $1^{10}$, whereas most $\mathrm{Tg}^{\mathrm{b} / \mathrm{d}} \mathrm{V \gamma 2} 2^{+}$IEL are HSA, $\mathrm{B} 220^{+}, \mathrm{CD}^{+}$, Thy 1-(Figure 5 and data not shown). This suggests that several additional developmental steps are required before $\mathrm{Tg}^{\mathrm{b} / \mathrm{d}} \mathrm{V} \gamma^{2}$ neonatal thymocytes can develop into $\mathrm{Tg}^{\mathrm{b} / \mathrm{d}}$ $\mathrm{V} \gamma 2^{+}$IEL. Whether these steps take place intrathymically or extrathymically (presumably at the intestinal epithelium) is unclear. The absence of a discrete population of $\mathrm{Tg}^{\mathrm{b} / \mathrm{d}} \mathrm{V} \gamma^{+}$neonatal thymocytes that phenotypically resemble $\mathrm{Tg}$ //d IEL suggests that despite their thymic origin, $\mathrm{Tg} \mathrm{b}^{\mathrm{b}} \mathrm{d} \gamma 2^{2}$ neonatal thymocytes differentiate further extrathymically before becoming $\mathrm{Tg}^{\mathrm{b} / \mathrm{d}} \mathrm{V} \mathbf{2}^{+}$ IEL. However, we can not rule out the possibility that a very small portion of $\mathrm{Tg}^{\mathrm{b} / \mathrm{d}} \mathrm{V} \gamma 2^{+}$neonatal thymocytes differentiates intrathymically before leaving the thymus and migrating to the intestinal epithelium.
Although this hypothesis is speculative, it may explain why the injection of $\mathrm{Tg}^{\mathrm{b} / \mathrm{d}}$ neonatal thymocytes was significantly less efficient at generating $\mathrm{Tg}^{\mathrm{b} / \mathrm{d}} \mathrm{V} \gamma 2^{2}$ IEL in the $\mathrm{TL}^{\mathrm{b}+}$ nude host than was grafting of the neonatal $\mathrm{Tg}^{\mathrm{b} / \mathrm{d}}$ thymus (compare Figure $2 \mathrm{~b}$ and Figure 3, top row). Our results with neonatal thymectomy and thymus grafting strongly suggest that most (if not all) $\mathrm{Tg}^{\mathrm{b} / \mathrm{d}}$ $\mathrm{V} \gamma 2^{+}$IEL are derived from the thymus. Thymectomy on day 2 almost completely eliminated Tgb/d $V \gamma 2$ IEL (Figure 1c), and grafting of the neonatal $\mathrm{Tg}^{\mathrm{b} / \mathrm{d}}$ thymus into a $\mathrm{TL}^{\mathrm{b}+}$ host generated very large numbers of $\mathrm{Tg}^{\mathrm{b} / \mathrm{d}} \mathrm{V} \gamma 2^{+}$ IEL (Figure 3, top row). At first sight, our results appear to directly conflict with the study by Barrett et al. (16), who used the adult thymectomy radiation bone marrow chimera (ATXBM) as a model for extrathymic Tcell development and concluded that $\mathrm{Tg} b / \mathrm{d} V 2^{+}$IEL are derived from an extrathymic pathway. Although we are willing to concede that some $\mathrm{Tg}^{\mathrm{b} / \mathrm{d}} \mathrm{V} \gamma^{+}$IEL can develop through such a pathway, several lines of reasoning suggest that the results of the ATXBM model probably exaggerate the significance of the this pathway. First, the radiation bone marrow chimera model only demonstrates that some $\mathrm{Tg} \mathrm{g}^{\mathrm{b} / \mathrm{d}} \mathrm{V} \gamma 2^{+}$IEL can develop through an extrathymic pathway. Second, the ATXBM
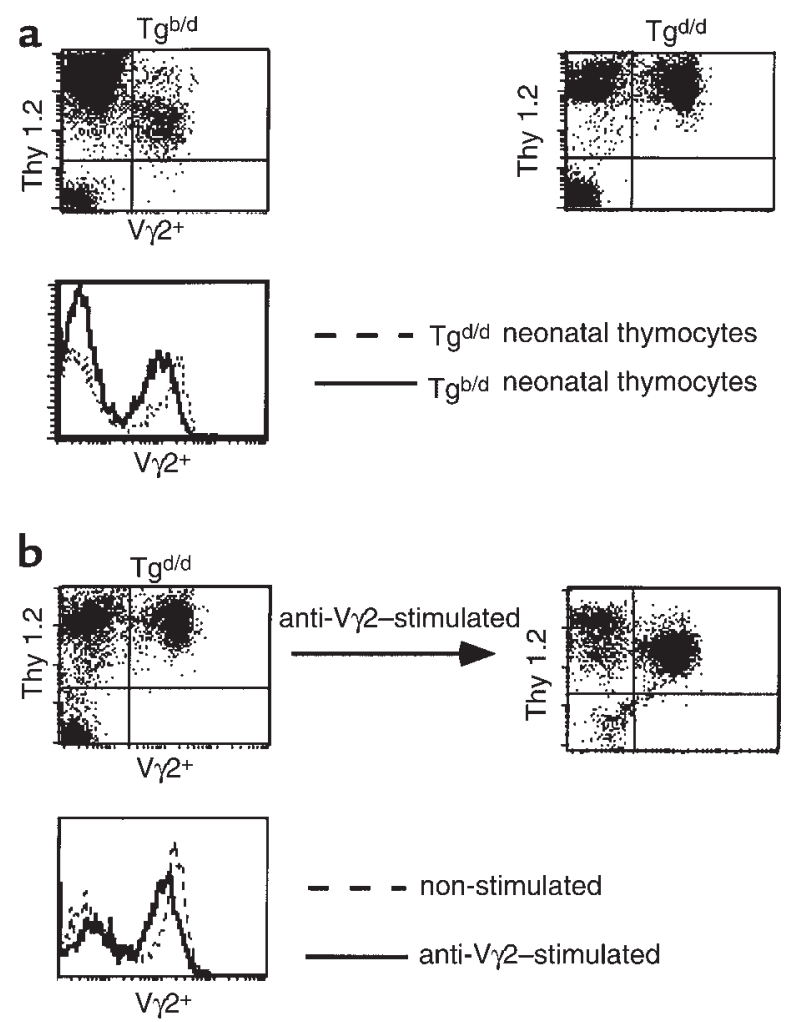

anti-V $\gamma 2-$ stimulated

\section{Figure 6}

Phenotypic examination of Thy 1 and $V \gamma 2^{+}$TCR levels suggests that most $\mathrm{Tg}^{\mathrm{b} / \mathrm{d}} \mathrm{V} \gamma 2^{+}$neonatal thymocytes have recognized the $T L^{\mathrm{b}} \mathrm{Ag}$. (a) $\mathrm{Tg} b / d \gamma^{+}$neonatal thymocytes express lower levels of Thy 1 and $V \gamma 2^{+} T C R$ than do $T g d / d ~ V \gamma 2^{+}$neonatal thymocytes. (b) Stimulation of $T g^{d / d}$ neonatal thymocytes with anti-V $\gamma 2$ TCR $m A b$ resulted in decreased levels of Thy 1 and $V \gamma 2^{+} T C R$. Data shown represent 1 of 2 separate experiments. 
model is not natural and does not duplicate normal ontogeny as well as the thymus graft and neonatal thymectomy experiments do. Lastly, radiation probably alters the intestinal epithelium so that it induces the appearance of T cells, which normally would not be there. To prove this, we injected $\mathrm{Tg}^{\mathrm{b} / \mathrm{d}}$ spleen cells (which have virtually no $V \gamma 2^{+} \mathrm{T}$ cells) into a $\mathrm{TL}^{\mathrm{b}+} \mathrm{RAG}$ null host and obtained virtually no $\mathrm{Tg} V \gamma 2^{+}$IEL, as expected. However, when we irradiated the $\mathrm{TL}^{\mathrm{b}+} \mathrm{RAG}$ null mice with 400 rads before injection of $\mathrm{Tgb} / \mathrm{d}$ spleen cells, there was an almost 30 -fold increase in Tg V $\gamma 2^{+}$IEL in the recipient $\mathrm{TL}^{\mathrm{b}+} \mathrm{RAG}$ null host (Lin et al., unpublished observations). Our conclusion is supported by the study of Rocha et al., who demonstrated that reconstitution of thymectomized, nonirradiated RAG null mice with bone marrow cells generated very few $\gamma \delta$ IEL (40). Collectively, these results suggest that most of the $\gamma \delta$ IEL seen in the ATXBM model probably would not appear under normal nonirradiated conditions, and that most $\gamma \delta$ IEL (including $\mathrm{Tg}^{\mathrm{b} / \mathrm{d}} \mathrm{V} \gamma 2^{+} \mathrm{IEL}$ ) are derived from the thymus.

If $\mathrm{Tg}^{\mathrm{b} / \mathrm{d}} \mathrm{V} \gamma 2^{+}$neonatal thymocytes can escape negative selection and efficiently migrate to and increase in number at the intestinal epithelium, as suggested by our data, it is unclear what purpose this would serve in developing a functional immune repertoire. Because our data suggest that most $\mathrm{Tg}^{\mathrm{b} / \mathrm{d}} \mathrm{V} \gamma 2^{+}$IEL are derived from the neonatal thymus, it is not surprising that the phenotype and the functional properties of $\mathrm{Tg}^{\mathrm{b} / \mathrm{d}}$ neonatal thymus-derived $V \gamma 2^{ \pm}$IEL are essentially the same as those of $\mathrm{Tg}^{\mathrm{b} / \mathrm{d}} \mathrm{V} \gamma 2^{+}$IEL. The latter have been extensively studied by Barrett et al. $(16,27)$, who demonstrated that $\mathrm{Tg}^{\mathrm{b} / \mathrm{d}} \mathrm{V} \gamma 2^{+}$IEL have acquired tolerance. Although the development of tolerance may protect the intestinal epithelium from being harmed by potentially autoreactive $\mathrm{T}$ cells, it is not clear what functional purpose would be served by expanding a large population of both tolerant and potentially autoreactive T cells. One possibility is that this pathway may be an efficient way of generating IEL that produce TH2-type cytokines rather than the TH1-type cytokines, which may be more harmful to the intestinal epithelium in an immune reaction. Using $2 \mathrm{C} \mathrm{Tg}$ mice that express an $\alpha \beta$ TCR that recognizes an endogenous peptide Ag presented by the MHC class I H-2Ld, Guehler et al. (41) demonstrated that Tg IEL from $\mathrm{Ag}^{+}$mice proliferated poorly and produced very little IL- 2 or IFN- $\gamma$, yet also demonstrated by RT-PCR that $\mathrm{Tg}$ IEL from $\mathrm{Ag}^{+}$mice were more likely than $\mathrm{Tg}$ IEL from their experimental Ag- mice to produce $\mathrm{TH} 2$ type cytokine IL-4. Whether this phenomenon occurs for $\alpha \beta$ IEL in other Tg mice or for our Tg V $\gamma 2+$ IEL has yet to be shown. Finally, our results may have some relevance to human $\gamma \delta$ IEL. Groh et al. recently demonstrated that some human $\gamma \delta$ IEL are capable of recognizing stress-induced self MHC class I-related molecules (42). Their results suggest that a similar pathway of development, which we have described here, may also occur for human $\gamma \delta$ IEL.

\section{Acknowledgments}

The authors would like to thank M. Kronnenberg and M. Huflejt for careful reading of the manuscript, $M$. Reaves for her secretarial assistance, and W.A. Olsen for his support. This research was supported by K08 Award DK-02445-01 to T. Lin and grant R01 GM-52735 (to D.R. Green) from the National Institutes of Health.

1. Kappler, J.W., Staerz, U., White, J., and Marrack, P.C. 1988. Self-tolerance eliminates T cells specific for Mls-modified products of the major histocompatability complex. Nature. 332:35-40.

2 Acha-Orbea, H., and Palmer, E. 1991. Mls: a retrovirus exploits the immune system. Immunol. Today. 12:356-361.

3. Dent, A.L., et al. 1990. Self-reactive gamma delta T cells are eliminated in the thymus. Nature. 343:714-719.

4. Teh, H.S., Kishi, H., Scott, B., and von Boehmer, H. 1989. Deletion of autospecific $\mathrm{T}$ cells in $\mathrm{T}$ cell receptor transgenic mice spare cells with normal TCR levels and low levels of CD8 molecules. J. Exp. Med. 169:795-806.

5. Kisielow, P., Bluethmann, H., Startz, U.D., Steinmetz, M., and von Boehmer, H. 1988. Tolerance in T cell receptor transgenic mice involves deletion of non-mature $\mathrm{CD}^{+} \mathrm{CD}^{+}$thymocytes. Nature. 333:742-746.

6. Sha, W.C., et al. 1988. Positive and negative selection of an antigen receptor on T cells in transgenic mice. Nature. 336:73-76.

7. Sha, W.C., et al. 1988. Selective expression of an antigen receptor on CD8-bearing T lymphocytes in transgenic mice. Nature. 335:271-274.

8. Speiser, D.E., et al. 1991. Neonatal tolerance to Mls-1a determinants: deletion or anergy of $\mathrm{V} \beta 6^{+} \mathrm{T}$ lymphocytes depending upon MHC compatibility of neonatally injected cells. Int. Immunol. 3:127-134.

9. Schneider, R., et al. 1989. Fate of potentially self-reactive T cells in neonatal mice: analysis of $\mathrm{V} \beta 6^{+} \mathrm{T}$ cells in Mls $\mathrm{s}^{\mathrm{a}}$ mice. Thymus. 13:35-43.

10. Schneider, R., et al. 1989. Postnatal disappearance of self-reactive (VB6) cells from the thymus of Mls a mice. J. Exp. Med. 169:2149-2154.

11. Teh, H.S., et al. 1990. Early deletion and late positive selection of T cells expressing a male-specific receptor in T-cell receptor transgenic mice. Dev. Immunol. 1:1-10.

12. Dent, A.L., Matis, L.A., Bluestone, J.A., and Hedrick, S.M. 1993. Evidence for programmed cell death of self-reactive gamma delta $\mathrm{T}$ cell receptorpositive thymocytes. Eur. J. Immunol. 23:2482-2487.

13. Bandeira, A., et al. 1991. Extrathymic origin of intestinal intraepithelial lymphocytes bearing T-antigen receptor $\gamma \delta$. Proc. Natl. Acad. Sci. USA. 88:43-47.

14. Sperling, A., et al. 1997. Selective expansion of Vgamma2-Vdelta7 TCR gamma delta cells in C57BL/6 mice is postnatal and extrathymic. $J$. Immunol. 159:86-91.

15. Yoshikai, Y., Reis, M.D., and Mak, T.W. 1986. Athymic mice express a high level of functional gamma-chain but greatly reduced levels of alphaand beta-chain T-cell receptor messages. Nature. 324:482-485.

16. Barrett, T.A., et al. 1992. Mechanism of self-tolerance of $\gamma / \delta$ T cells in epithelial tissue. J. Exp. Med. 175:65-70.

17. Rocha, B., Vassalli, P., and Guy-Grand, D. 1991. The V $\beta$ repertoire of mouse gut homodimeric alpha CD8 ${ }^{+}$intraepithelial T cell receptor $\alpha \beta^{+}$ lymphocytes reveals a major extrathymic pathway of $\mathrm{T}$ cell differentiation. J. Exp. Med. 173:483-486.

18. Rocha, B., von Boehmer, H., and Guy-Grand, D. 1992. Selection of intraepithelial lymphocytes with CD8 alpha/alpha co-receptors by self antigen in the murine gut. Proc. Natl. Acad. Sci. USA. 89:5336-5340.

19. Poussier, P., Teh, H.S., and Julius, M. 1993. Thymus-independent positive and negative selection of $\mathrm{T}$ cells expressing a major histocompatibility complex class I restricted transgenic T cell receptor $\alpha \beta$ in the intestinal epithelium. J. Exp. Med. 178:1947-1957.

20. Cruz, D., et al. 1998. An opposite pattern of selection of a single T cell antigen receptor in the thymus and among intraepithelial lymphocytes. J. Exp. Med. 188:255-265.

21. Rocha, B., Vassalli, P., and Guy-Grand, D. 1992. The extrathymic T cell development pathway. Immunol. Today. 13:449-454.

22. Lin, T., Matsuzaki, G., Kenai, H., and Nomoto, K. 1995. Extrathymic and thymic origin of IEL: are most IEL in euthymic mice derived from the thymus? Immunol. Cell Biol. 73:469-473.

23. Lefrancois, L., and Puddington, L. 1995. Extrathymic intestinal T-cell development: virtual reality. Immunol. Today. 16:16-21.

24. Matsuzaki, G., Lin, T., and Nomoto, K. 1994. Differentiation and function of intestinal intraepithelial lymphocytes. Int. Rev. Immunol. 11:47-53.

25. Lin, T., Matsuzaki, G., Kishihara, K., Mak, T.W., and Nomoto, K. 1994. Characteristics of fetal thymus-derived $\mathrm{T}$ cell receptor $\gamma \delta$ intestinal intraepithelial lymphocytes. Eur. J. Immunol. 24:1792-1798.

26. Lefrancois, L., and Olsen, S. 1994. A novel pathway of thymus-directed T lymphocyte maturation. J. Immunol. 157:987-995.

27. Barrett, T.A., Tatsumi, Y., and Bluestone, J.A. 1993. Tolerance of T cell 
receptor $\gamma \delta$ cells in the intestine. J. Exp. Med. 177:1755-1762.

28. Lin, T., et al. 1994. $\mathrm{CD}^{-} \mathrm{CD}^{+}$intestinal intraepithelial lymphocytes (IEL) and the extrathymic development of IEL. Eur. J. Immunol. 24:1080-1087.

29. Sjodin, K., Dalmasso, A.P., Smith, J.M., and Martinez, C. 1966. Thymectomy in newborn and adult mice. Transplantation. 1:521-525.

30. Lin, T., Matsuzaki, G., Kenai, H., Nakamura, T., and Nomoto, K. 1993. Thymus influences the development of extrathymically derived intestinal intraepithelial lymphocytes early in ontogeny. Eur. J. Immunol. 23:1968-1974.

31. Lin, T., Matsuzaki, G., Kenai, H., and Nomoto, K. 1994. Progenies of fetal thymocytes are the major source of $\mathrm{CD}^{-}{ }^{-} \mathrm{CD}^{+} \alpha \alpha$ intestinal intraepithelial lymphocytes early in ontogeny. Eur. J. Immunol. 31:1785-1791.

32. Lin, T., et al. 1998. Fas-ligand-mediated killing by intestinal intraepithelial lymphocytes. J. Clin. Invest. 101: 570-577.

33. Schild, H., et al. 1994. The nature of MHC recognition by $\gamma / \delta$ T cells. Cell. 76:29-36.

34. Weintraub, B.C., Jackson, M.R., and Hedrick, S.M. 1994. $\gamma \delta$ T cells can recognize nonclassical MHC in the absence of conventional antigenic peptides. J. Immunol.153:3051-3058.

35. Guy-Grand, D., et al. 1992. Different expression of the recombinant acti- vating gene RAG-1 in various populations of thymocytes, peripheral $\mathrm{T}$ cells and gut thymus-independent intraepithelial lymphocytes suggest two pathways of $\mathrm{T}$ cell receptor rearrangement. Eur. J. Immunol. 22:505-510.

36. Budd, R.C., et al. 1987. Distinction of virgin and memory T lymphocytes. J. Immunol. 138:3120-3124.

37. Wells, F.B., et al. 1993. Phenotypic and functional analysis of positive selection in the $\gamma \delta \mathrm{T}$ cell lineage. J. Exp. Med. 177:1061-1070.

38. Schweighoffer, E., and Fowlkes, B.J. 1996. Positive selection is not required for thymic maturation of transgenic $\gamma \delta \mathrm{T}$ cells. J. Exp. Med. 183:2033-2041.

39. Pereira, P., and Tonegawa, S. 1993. Gamma/delta cells. Annu. Rev. Immunol. 35:637-685.

40. Rocha, B., Vassalli, P., and Guy-Grand, D. 1994. Thymic and extrathymic origins of gut intraepithelial lymphocyte populations in mice. J. Exp. Med. 180:681-686.

41. Guehler, S.R., Bluestone, J.A., and Barrett, T.A. 1996. Immune deviation of $2 \mathrm{C}$ transgenic intraepithelial lymphocytes in antigen-bearing hosts. J. Exp. Med. 184:493-503.

42. Groh, V., Steinle, A., Bauer, S., and Spies, T. 1998. Recognition of stressinduced MHC molecules by intestinal epithelial gamma-delta T cells. Science. 13:1737-1740. 